\title{
A preliminary evaluation of ZSM-5/SBA-15 composite supported Co catalysts for Fischer-Tropsch synthesis
}

\author{
Liyang $\mathrm{Wu}^{\mathrm{a}, \mathrm{c}}$, Zhuo Li ${ }^{\mathrm{a}, *}$, Dezhi Han ${ }^{\mathrm{a}}$, Jinhu Wu ${ }^{\mathrm{a}, \mathrm{b}}$, Dongke Zhang ${ }^{\mathrm{a}, \mathrm{b}}$ \\ a Key Laboratory of Biofuels, Qingdao Institute of Bioenergy and Bioprocess Technology, Chinese Academy of Sciences, Qingdao 266101, PR China \\ b Centre for Energy (M473), The University of Western Australia, 35 Stirling Highway, Crawley, WA 6008, Australia \\ c University of Chinese Academy of Sciences, Beijing 100049, PR China
}

\section{A R T I C L E I N F O}

\section{Article history:}

Received 27 October 2014

Received in revised form 24 February 2015

Accepted 27 February 2015

Available online 14 March 2015

\section{Keywords:}

Catalysis

Cobalt

Fischer-Tropsch synthesis

Hydrocarbons

Selectivity

ZSM-5/SBA-15 composite

\begin{abstract}
A B S T R A C T
A series of ZSM-5/SBA-15 composite supported Co catalysts were prepared and evaluated for the Fischer-Tropsch synthesis (FTS) aimed to maximise the selectivity of $\mathrm{C}_{5}-\mathrm{C}_{22}$ hydrocarbons in the product. The composite support was prepared by physically mixing ZSM- 5 and SBA- 15 of varying proportions and the finished catalysts had a constant Co loading of $15 \mathrm{wt}$.\%. The catalysts were tested for their performance in a high pressure fixed-bed reactor operating at $\mathrm{T}=240{ }^{\circ} \mathrm{C}, \mathrm{P}=2.0 \mathrm{MPa}, \mathrm{H}_{2} / \mathrm{CO}=2$ and $\mathrm{GHSV}=1000 \mathrm{~h}^{-1}$. The composite supported catalysts were shown to have much improved catalytic performance over the respective single material supported catalysts. The catalyst with 20wt.\% ZSM-5 in the composite support gave the maximum CO conversion (90.6\%), maximum selectivity of $\mathrm{C}_{5}-\mathrm{C}_{22}$ hydrocarbons (70.0\%) and minimum selectivity of light hydrocarbons (13.3\% for $\mathrm{CH}_{4}$ and $7.0 \%$ for $\mathrm{C}_{2}-\mathrm{C}_{4}$ alkanes). The catalysts were characterized using $\mathrm{X}$-ray diffraction, $\mathrm{X}$-ray photoelectron spectroscopy, scanning electron microscopy, transmission electron microscopy with an energy dispersive X-ray spectrometer, temperature programmed desorption and temperature programmed reduction. It was revealed that the superior catalytic performance can be attributed to the large pore size and high dispersion of $\mathrm{CO}_{3} \mathrm{O}_{4}$, which afforded an optimum reducibility and acid site density.
\end{abstract}

(c) 2015 Elsevier B.V. All rights reserved.

\section{Introduction}

The Fischer-Tropsch synthesis (FTS) process is a collection of chemical reactions that converts a mixture of carbon monoxide and hydrogen, also known as syngas, into clean liquid fuels or valuable chemicals [1-4]. Its products are a wide-range of hydrocarbons from $\mathrm{CH}_{4}$ to heavy molecular weights and can be sulphur- and nitrogenfree with high cetane number fuels, usually following an AndersonSchulz-Flory distribution [5,6]:

$W_{n} / n=(1-\alpha)^{2} \alpha^{n-1}$

where $W_{n}$ is the weight fraction of hydrocarbon molecules containing $n$ carbon atoms and $\alpha$ is the chain growth probability determined by the catalyst and the specific process conditions. It can be explained by the chain growth mechanism of hydrogenation of $\mathrm{CO}$, the hydrogenolysis (cleavage with $\mathrm{H}_{2}$ ) of $\mathrm{C}-\mathrm{O}$ bonds and the formation of $\mathrm{C}-\mathrm{C}$ bonds. Iron $(\mathrm{Fe})$, cobalt $(\mathrm{Co})$, and ruthenium ( $\mathrm{Ru})$ are among the most studied metals in formulating the Fischer-Tropsch catalysts. The high cost of $\mathrm{Ru}$ has hindered its industrial-scale application and as such, $\mathrm{Ru}$ is often limited to laboratory studies [2,7]. Between Fe and Co, Co-based

\footnotetext{
* Corresponding author. Tel./fax: + 8653280662763.

E-mail address: lizhuo@qibebt.ac.cn (Z. Li).
}

catalysts for FTS are usually preferred due to their high selectivity in linear paraffin fractions, slow deactivation, less oxygenates and low water-gas shift (WGS) activity [2,8-11]. Although many catalysts have been developed, selectivity control towards gasoline and middle distillate is one of the most important and difficult challenges.

One possible means to control the products is to use the support with controllable pore sizes [2]. The use of periodic mesoporous silicas, for instance, MCM-41 and SBA-15, as supports for preparing Co-based FTS catalysts has been explored [12-15]. The size-controlled pore distribution and high surface area of SBA-15 allows for restricting the formation of hydrocarbons longer than some characteristic size (say, carbon number $n<20$ ), as well as a better control on the cobalt particle size and higher dispersions at higher Co loading as compared to conventional amorphous silica. Martínez et al. [12] studied the influence of cobalt precursor and loading as well as promoters on the catalytic properties of Co/SBA-15 for Fischer-Tropsch synthesis. Catalysts prepared from organic cobalt precursors showed very low FTS activities than those prepared from cobalt nitrate. Xiong et al. [15] investigated the role of pore size in $\mathrm{Co}_{\mathrm{SBA}}-15$ as a FTS catalyst and found that the $\mathrm{C}_{5}$ + selectivity increased with increasing the SBA-15 pore size up to $9.32 \mathrm{~nm}$ but remained unchanged for larger pore sizes.

It was also well established that the acidic zeolite as a catalyst support or in combination with the conventional support could lead to the enhanced selectivity of gasoline [6,16,17]. Li et al. [18] studied 
gasoline-range hydrocarbon synthesis with $\mathrm{CO}_{2}$-containing syngas by using $\mathrm{SiO}_{2} / \mathrm{HZSM}-5$ hybrid-supported $\mathrm{Co}$ catalysts. The $\mathrm{CO}_{2}$ conversion reached the maximum of $20.3 \%$ at $\mathrm{CO}_{2} /\left(\mathrm{CO}+\mathrm{CO}_{2}\right)$ ratio of 0.42 . Sartipi et al. [19] introduced mesopores into the structure of HZSM-5 used as support. The $\mathrm{Co} / \mathrm{mesoH}-\mathrm{ZSM}-5$ showed higher selectivity of the gasoline-range products than $\mathrm{Co} / \mathrm{H}-\mathrm{ZSM}-5$. However, the activity of catalysts based on mesoH-ZSM- 5 decreased quickly in just $30 \mathrm{~h}$. The $\mathrm{SiO}_{2} / \mathrm{Al}_{2} \mathrm{O}_{3}$ ratio and the crystal size of $\mathrm{ZSM}-5$ have a strong effect on the catalytic performance and product selectivity. The strong acidity and long-path micropores usually cause the over-cracking to undesirable light hydrocarbons $\left(\mathrm{CH}_{4}\right.$ and $\mathrm{C}_{2}-\mathrm{C}_{4}$ alkanes) [20].

The present contribution reports a preliminary experimental evaluation of ZSM-5/SBA-15 composite supported cobalt catalysts for FTS. It was expected that the combination of SBA-15 with controlled pore sizes and ZSM- 5 with proper acidity would facilitate much improved selectivity of the gasoline and middle distillate range hydrocarbons.

\section{Experimental}

\subsection{Catalyst preparation}

SBA-15 was prepared as follows: $4.0 \mathrm{~g}$ P123 (EO20PO70EO20, $\mathrm{MAV}=5800$, Aldrich) was dissolved in $120 \mathrm{~mL} 2 \mathrm{M} \mathrm{HCl}$ with stirring to obtain a clear solution. $8.5 \mathrm{~g}$ TEOS (Aldrich) was gradually added into the solution with continuous stirring for $24 \mathrm{~h}$. The mixture was hydrothermally processed to crystallize in a Teflon-lined autoclave at $120{ }^{\circ} \mathrm{C}$ for $24 \mathrm{~h}$ followed by filtering, washing and drying at room temperature. Calcination of the dried cake was then carried out in an electric oven in air at $550{ }^{\circ} \mathrm{C}$ for $6 \mathrm{~h}$.

ZSM-5 $\left(\mathrm{SiO}_{2} / \mathrm{Al}_{2} \mathrm{O}_{3}=40\right)$ was obtained from Qilu Huaxin Industry Co. Ltd. The composite supports were prepared by physically mixing the SBA-15 with the ZSM-5 in different mass ratios. The prepared composites were denoted as ZS-X, where $\mathrm{x}=0,10,20,30,50$, and 100 , respectively, representing the percent of ZSM-5 in the composite.

$\mathrm{Co} / \mathrm{ZS}-\mathrm{x}$ catalysts were prepared by incipient wet impregnation [21, 22 ] of the respective ZS-X supports with a desired amount of aqueous cobalt nitrate. The precursors were dried at $120{ }^{\circ} \mathrm{C}$ and calcined at $400{ }^{\circ} \mathrm{C}$ for $4 \mathrm{~h}$. The content of cobalt in the final catalysts was kept constant at $15 \mathrm{wt} . \%$.

\subsection{Catalyst characterization}

Surface area and porosity were measured using $\mathrm{N}_{2}$ adsorptiondesorption at $-196{ }^{\circ} \mathrm{C}$ on an ASAP-2010 Micromeritics instrument. Prior to a measurement, the sample was degassed at $300{ }^{\circ} \mathrm{C}$ for $6 \mathrm{~h}$. The surface area was obtained using the BET method, the micropore volume was calculated using the t-plot method [17] and the mesopore volume was calculated using the BJH method [23].

$\mathrm{X}$-ray diffraction patterns of the catalysts were collected on a Brukers D8 powder X-ray diffractometer with $\mathrm{Cu}-\mathrm{K} \alpha$ radiation at a rate of $4^{\circ} \mathrm{min}^{-1}$ in the range $2 \theta=5^{\circ}-70^{\circ}$. The average crystal size of $\mathrm{Co}_{3} \mathrm{O}_{4}$ was calculated according to the Scherrer equation at $2 \theta=36.9^{\circ}$, and the $\mathrm{Co}^{0}$ dispersion was also estimated according to the literature $[12,17]$, specifically, it was estimated from " $D=96 / d$, where $D$ is the $\%$ dispersion and $\mathrm{d}$ is the particle size of $\mathrm{Co}^{0}$ in $\mathrm{nm}$ which equals $0.75 \times \mathrm{d}\left(\mathrm{CO}_{3} \mathrm{O}_{4}\right)$."

The surface concentration and oxidation states of cobalt oxides on the catalysts were determined using X-ray photoelectron spectroscopy (XPS) performed on a Physical Electronics Company Quantum-2000 Scanning ESCA Microprobe spectrometer with a $\mathrm{Al} \mathrm{K \alpha}$ monochromatized line $(1486.6 \mathrm{eV})$. All binding energies (BEs) were corrected with reference to the $\mathrm{C} 1 \mathrm{~s}(284.6 \mathrm{eV})$. The morphology of the catalyst samples was investigated using scanning electron microscopy (SEM) with a JEOL JSM-7001 F microscope operated at $10 \mathrm{kV}$. Transmission electron microscopy (TEM) imaging analysis was carried out using a JEM-2010 microscope operated at $200 \mathrm{kV}$, equipped with an energy dispersive X-ray spectrometer (EDS) attachment (Oxford INCA Penta FETx3).

The acidity of the catalysts was analysed by using temperature programmed desorption ( $\left.\mathrm{NH}_{3}-\mathrm{TPD}\right)$. The sample was pretreated at $300{ }^{\circ} \mathrm{C}$ for $2 \mathrm{~h}$ in $\mathrm{Ar}$ and cooled to $50{ }^{\circ} \mathrm{C}$. After being saturated with $\mathrm{NH}_{3}$, the sample was purged with Ar to remove the physisorbed $\mathrm{NH}_{3}$. The TPD measurements of desorbed $\mathrm{NH}_{3}$ were conducted in flowing Ar from $50{ }^{\circ} \mathrm{C}$ to $650{ }^{\circ} \mathrm{C}$ at a heating rate of $10^{\circ} \mathrm{C} \mathrm{min}{ }^{-1}$. All flow rates of Ar mentioned above were set to $40 \mathrm{~mL} \mathrm{~min}^{-1}$.

The reduction behaviour of the supported cobalt phases was performed in a U-tube quartz cell. It was initially purged with $\mathrm{Ar}$ (40 $\mathrm{mL} \mathrm{min}{ }^{-1}$ ) at $300{ }^{\circ} \mathrm{C}$ for $1 \mathrm{~h}$ and cooled to $50{ }^{\circ} \mathrm{C}$, then exposed to $10 \% \mathrm{H}_{2} / \mathrm{Ar}\left(40 \mathrm{~mL} \mathrm{~min}^{-1}\right.$ ) while the temperature was ramped from $50{ }^{\circ} \mathrm{C}$ to $800{ }^{\circ} \mathrm{C}$ at a heating rate of $10{ }^{\circ} \mathrm{C} \mathrm{min}^{-1}$.

\subsection{Catalytic performance test}

The FTS reaction was performed in a stainless-steel fixed-bed reactor $\left(\mathrm{d}_{\text {int }}=8 \mathrm{~mm}\right)$. A catalyst of $\sim 1.0 \mathrm{~g}(250-400 \mu \mathrm{m}$ and $\sim 1.5 \mathrm{~mL}$ in volume $)$ was well mixed with $1.5 \mathrm{~mL}$ of quartz particles $(250-400 \mu \mathrm{m})$ and charged into the reactor to form a $\sim 3 \mathrm{~mL}$ diluted catalyst bed to avoid the formation of hot spots in the catalyst. The catalyst was then reduced in-situ in a $\mathrm{H}_{2}$ stream at $50 \mathrm{~mL} \mathrm{~min}^{-1}$ at $450{ }^{\circ} \mathrm{C}$ for $6 \mathrm{~h}$. During the FTS reaction tests, the reactant gas mixture composed of $\mathrm{H}_{2} / \mathrm{CO} / \mathrm{N}_{2}=6 / 3 / 1$ $(\mathrm{v} / \mathrm{v})$ was introduced into the reactor with the reaction condition of $240{ }^{\circ} \mathrm{C}, 2 \mathrm{MPa}$ and space velocity (GHSV) of $1000 \mathrm{~h}^{-1}$. The reactor effluent passed through a hot trap and a cold trap to collect the products. The gas effluent was analysed on-line for its composition by using an Agilent 7890 chromatograph equipped with a thermal conductivity detector (TCD) and a flame ionization detectors (FID). Another gas chromatograph (Agilent 7820A) equipped with a DB-1 capillary column was used to analyse the composition of the liquid products. Each experimental run was repeated at least three times and the carbon balance was also estimated as a means of confirming the validity of the experimental runs. It was found that above $90 \%$ carbon balance was achieved for all reported experiments.

\section{Results and discussion}

\subsection{Performance of the catalysts in Fischer-Tropsch synthesis}

As summarized in Table 1, the composite supported catalysts clearly displayed superior catalytic performance compared to the respective single materials supported catalysts. The composite supported catalysts showed a low selectivity of $C_{1}-C_{4}$ hydrocarbons and high selectivity of $\mathrm{C}_{5}-\mathrm{C}_{22}$. Although the $\mathrm{CO}$ conversion was not significantly altered with increasing the ratio of ZSM-5 in the composite up to 20\%, the selectivity of the $\mathrm{CH}_{4}$ and $\mathrm{C}_{2}-\mathrm{C}_{4}$ hydrocarbons drastically decreased and the selectivity of the $\mathrm{C}_{5}-\mathrm{C}_{22}$ range of hydrocarbons was enhanced. Note especially that the selectivity of the middle distillate hydrocarbons $\mathrm{C}_{12}-\mathrm{C}_{22}$ had increased from $26.6 \%$ for Co/ZS-0 to $38.0 \%$ for Co/ZS-20. This is believed to be related to the higher cobalt dispersion and larger pore sizes in the catalysts with a higher ratio of ZSM-5 up to $20 \%$

Table 1

The activity and selectivity results for the FTS reaction over the Co/ZS-x series catalysts.

\begin{tabular}{lllllllll}
\hline Catalyst & \multirow{2}{*}{$\begin{array}{l}\text { CO conversion } \\
\text { (\%) }\end{array}$} & \multicolumn{7}{l}{ Hydrocarbon selectivity (\%) } \\
\cline { 3 - 9 } & & $\mathrm{CH}_{4}$ & $\mathrm{C}_{2}-\mathrm{C}_{4}$ & $\mathrm{C}_{5}+$ & $\mathrm{C}_{5}-\mathrm{C}_{11}$ & $\mathrm{C}_{12}-\mathrm{C}_{22}$ & $\mathrm{C}_{5}-\mathrm{C}_{22}$ & $\mathrm{C}_{23+}$ \\
\hline $\mathrm{Co} / \mathrm{ZS}-0$ & 90.0 & 23.4 & 11.5 & 65.1 & 33.9 & 26.6 & 60.5 & 4.7 \\
$\mathrm{Co} / \mathrm{ZS}-10$ & 90.2 & 21.4 & 10.0 & 68.8 & 33.1 & 29.3 & 62.4 & 6.4 \\
$\mathrm{Co} / \mathrm{ZS}-20$ & 90.6 & 13.3 & 7.0 & 79.7 & 32.0 & 38.0 & 70.0 & 9.7 \\
$\mathrm{Co} / \mathrm{ZS}-30$ & 87.9 & 13.8 & 8.8 & 77.3 & 33.6 & 35.2 & 68.8 & 8.5 \\
$\mathrm{Co} / \mathrm{ZS}-50$ & 84.9 & 18.7 & 9.4 & 71.9 & 34.7 & 30.7 & 65.4 & 6.5 \\
$\mathrm{Co} / \mathrm{ZS}-100$ & 70.5 & 18.5 & 12.0 & 69.6 & 23.9 & 34.1 & 58.0 & 11.6 \\
\hline
\end{tabular}

Reaction conditions: $\mathrm{T}=240{ }^{\circ} \mathrm{C}, \mathrm{P}=2.0 \mathrm{MPa}, \mathrm{H}_{2} / \mathrm{CO}=2$ and $\mathrm{GHSV}=1000 \mathrm{~h}^{-1}$. 
(as evidenced by the XRD and BET results in Tables 4 and 3), which benefited the production of long chain hydrocarbons but not the $\mathrm{CH}_{4}$ and $\mathrm{C}_{2}-\mathrm{C}_{4}$ hydrocarbons [24]. Meanwhile, the addition of ZSM-5 is also thought to facilitate the cracking of longer chain hydrocarbons to $\mathrm{C}_{5}-\mathrm{C}_{22}$. However, with the further increase in the proportion of ZSM-5, the CO conversion decreased to $87.9 \%$ for $\mathrm{Co} / \mathrm{ZS}-30$ and $84.9 \%$ for Co/ZS-50, accompanied by increased selectivity of $\mathrm{CH}_{4}$ and $\mathrm{C}_{2}-\mathrm{C}_{4}$ hydrocarbons and lowered selectivity of $\mathrm{C}_{5}-\mathrm{C}_{22}$ hydrocarbons. Compared to the physically mixing of $\mathrm{Co} / \mathrm{SiO}_{2}$ and $\mathrm{HZSM}-5$ reported in the literature [17], the present ZSM-5/SBA-15 composite supported Co catalysts clearly showed a higher selectivity towards $C_{12}-C_{22}$. For catalyst $\mathrm{Co} / \mathrm{ZS}-100$ with only ZSM-5 as the support, however, the CO conversion and selectivity of $C_{5}-C_{22}$ were only $70.5 \%$ and $58.0 \%$, respectively, while the products shifted to heavier hydrocarbons $\mathrm{C}_{23}$ + (with a yield as high as $11.6 \%$ ). Although, due to its high acidity, ZSM-5 has a tendency to crack hydrocarbons to lighter products, the FTS process involves competing reactions of both chain-growth and cracking simultaneously. The low content of alumina (silica/alumina $=36$ ) and large crystal size of $\mathrm{Co}_{3} \mathrm{O}_{4}$ is thought to favour the formation of long-chain products $[25,33]$. In the present work, the silica/alumina ratio of ZSM-5 was 40 and the crystal size of $\mathrm{CO}_{3} \mathrm{O}_{4}$ in the $\mathrm{Co} / \mathrm{ZS}-100$ catalyst was estimate to be $26.0 \mathrm{~nm}$, which facilitated more chain-growth than cracking. Thus the $\mathrm{C}_{12}-\mathrm{C}_{22}$ selectivity was as high as $34.1 \%$ and the $\mathrm{C}_{23}$ + selectivity was also the highest on the Co/ZS-100 catalyst.

An effort was made to compare the present results against the literature data (as listed in Table 2), albeit the difficulties in finding literature information on the same catalysts and reaction conditions. Nevertheless, the present work generally achieved higher CO conversions. This might be in part due to the lower space velocity employed in the present work. The $C_{5}$ selectivity was within the range of the literature data. Since the cobalt content in the present catalyst was less than those of the others, the amount of the heavy products was slightly less. It is worthwhile to note that with 20\% ZSM-5 in the composite support, the $C_{5}$ selectivity increased to a level comparable to the literature and more importantly, the yield of the diesel range products $\left(\mathrm{C}_{12}-\mathrm{C}_{18}\right)$ of this work was noticeably higher, indicating some advantages and the synergistic effect of the ZSM-5/SBA-15 composite support [20].

\subsection{Textural properties of catalysts}

Compared with SBA-15 and ZSM-5, the catalysts Co/ZS-0 and Co/ZS-100 showed a decrease in the BET surface area, as shown in Table 3. This could be ascribed to the dilution effect of the supported cobalt oxide phase [31]. The BET surface area, as well as pore volume, had a distinct decrease when more than $20 \%$ ZSM-5 was introduced into the support. This was due to the lower BET surface area and pore volume of ZSM-5 as shown in Table 3. While the observed slight
Table 3

Textural properties of the samples.

\begin{tabular}{llllll}
\hline Sample & $\begin{array}{l}\text { BET } \\
\text { surface area } \\
\left(\mathrm{m}^{2} / \mathrm{g}\right)\end{array}$ & $\begin{array}{l}\text { Pore } \\
\text { volume } \\
\left(\mathrm{cm}^{3} / \mathrm{g}\right)\end{array}$ & $\begin{array}{l}\text { Micropore } \\
\text { volume } \\
\left(\mathrm{cm}^{3} / \mathrm{g}\right)\end{array}$ & $\begin{array}{l}\text { Mesopore } \\
\text { volume } \\
\left(\mathrm{cm}^{3} / \mathrm{g}\right)\end{array}$ & $\begin{array}{l}\text { Average } \\
\text { pore size } \\
(\mathrm{nm})\end{array}$ \\
\hline SBA-15 & 486 & 0.28 & 0.04 & 0.21 & 2.4 \\
ZSM-5 & 398 & 0.16 & 0.16 & 0 & 1.6 \\
Co/ZS-0 & 382 & 0.28 & 0.03 & 0.15 & 3.0 \\
Co/ZS-10 & 396 & 0.29 & 0.11 & 0.16 & 2.8 \\
Co/ZS-20 & 387 & 0.30 & 0.10 & 0.17 & 3.0 \\
Co/ZS-30 & 316 & 0.23 & 0.09 & 0.12 & 2.9 \\
Co/ZS-50 & 309 & 0.24 & 0.10 & 0.12 & 3.0 \\
Co/ZS-100 & 273 & 0.15 & 0.08 & 0.05 & 2.2 \\
\hline
\end{tabular}

increase for Co/ZS-10 and Co/ZS-20 was attributed to the small fraction of ZSM- 5 in the support. For Co/ZS-0, SBA-15 pores were clogged by cobalt species that made them inaccessible for nitrogen adsorption. Since the Co/ZSM-5 was prepared by incipient wetness impregnation and the cobalt content was $15 \mathrm{wt} . \%$, the chance for to enter into the micropores of ZSM-5 was usually low and $\mathrm{CoO}_{\mathrm{x}}$ was most likely to migrate and aggregate on the surface of ZSM-5 [34,35,43]. As a result, the cobalt species did not affect the nitrogen adsorption behaviour of ZSM-5. However, the average surface area and pore volume of the support decreased markedly if more ZSM-5 was added in the support. The presence of SBA-15 and its mesoporous structure favoured the formation of $\mathrm{C}_{5+}$ [14]. Note that $\mathrm{Co} / \mathrm{ZS}-20$ had the highest pore volume and pore size among all the catalysts. The good performance of Co/ZS-20 can at least be partly attributed to the pore size distribution [36].

\subsection{Crystalline phase of catalysts}

As shown in Fig. 1, the XRD peaks ascribed to ZSM-5 became more intense with increasing ZSM-5 in the catalyst as expected, while all catalysts showed the presence of well-defined reflection characteristics for $\mathrm{Co}_{3} \mathrm{O}_{4}$ at $31.3^{\circ}, 36.8^{\circ}, 44.8^{\circ}, 59.4^{\circ}$ and $65.2^{\circ}$, indicating the presence of crystalline cobalt species of $\mathrm{Co}_{3} \mathrm{O}_{4}$ spinel [8]. The nano crystal size thus determined offered an opportunity to examine the effect of nano crystal sizes of the composite materials in catalysis while it is understood that the absolute crystal sizes may not be highly accurate [37]. The trend of the estimated average crystal size of $\mathrm{Co}_{3} \mathrm{O}_{4}$ and the corresponding $\mathrm{Co}^{0}$ dispersion with varying amount of ZSM- 5 in the catalysts took a volcanic shape with Co/ZS-20 being the smallest crystal size of $12.1 \mathrm{~nm}$ and greatest dispersion of $10.6 \%$, as listed in Table 4 . The $\mathrm{CO}_{3} \mathrm{O}_{4}$ crystal sizes in the composite supported catalysts were smaller than in the single SBA-15 and ZSM-5 supported catalysts (14.1 nm for $\mathrm{Co} / \mathrm{ZS}-0$ and $26.0 \mathrm{~nm}$ for Co/ZS-100). This dispersion trend was also in accordance with the variation trend of $\mathrm{CO}$ conversion and the selectivity of $\mathrm{C}_{5}-\mathrm{C}_{22}$ for the catalysts. Small crystal sizes and high dispersion of

Table 2

A comparison of the present results with the literature data on the FTS reactions.

\begin{tabular}{|c|c|c|c|c|c|c|c|c|c|c|c|c|}
\hline Sample & $\begin{array}{l}\text { Co loading } \\
(\%)\end{array}$ & $\begin{array}{l}\mathrm{T} \\
\left({ }^{\circ} \mathrm{C}\right)\end{array}$ & $\begin{array}{l}\mathrm{P} \\
(\mathrm{MPa})\end{array}$ & SV & $\mathrm{H}_{2} / \mathrm{CO}$ & $\begin{array}{l}\mathrm{X}(\mathrm{CO}) \\
(\%)\end{array}$ & $\begin{array}{l}\mathrm{S}\left(\mathrm{CH}_{4}\right) \\
(\%)\end{array}$ & $\begin{array}{l}\mathrm{S}\left(\mathrm{C}_{2}-\mathrm{C}_{4}\right) \\
(\%)\end{array}$ & $\begin{array}{l}\mathrm{S}\left(\mathrm{C}_{5+}\right) \\
(\%)\end{array}$ & $\begin{array}{l}\mathrm{S}\left(\mathrm{C}_{5}-\mathrm{C}_{11}\right) \\
(\%)\end{array}$ & $\begin{array}{l}S\left(C_{12}-C_{18}\right) \\
(\%)\end{array}$ & Reference \\
\hline 20CoSBA-n & 18.0 & 220 & 2.0 & $13.5 \mathrm{~L} / \mathrm{g} / \mathrm{h}$ & 2 & 23.1 & 19.5 & 15.8 & 64.7 & 1 & l & {$[12]$} \\
\hline $\mathrm{Co} / \mathrm{SiO}_{2}+\mathrm{ZSM}-5$ & 19.5 & 250 & 2.0 & $13.5 \mathrm{~L} / \mathrm{g} / \mathrm{h}$ & 2 & $45-60$ & 11.0 & 14.7 & 74.3 & $62.2\left(C_{5}-C_{12}\right)$ & $11\left(C_{13}-C_{22}\right)$ & [17] \\
\hline Co/SBA-15 & 18.1 & 250 & 1.0 & $12.1 \mathrm{~L} / \mathrm{g} / \mathrm{h}$ & 2 & 63.2 & 22.3 & 5.7 & 71.1 & / & / & [26] \\
\hline Co/7SBA_L & $20.5 \mathrm{Ru}(0.3)$ & 220 & 2.0 & / & 2 & 55 & 13.5 & 14.0 & 72.5 & / & / & [27] \\
\hline Co/11SBA_M & $20.8 \mathrm{Ru}(0.2)$ & 220 & 2.0 & / & 2 & 55 & 10.1 & 9.2 & 80.8 & / & / & [27] \\
\hline $\mathrm{Co} / \mathrm{SBA}$ & 20 & 240 & 2.0 & $1000 \mathrm{~h}^{-1}$ & 2 & 60.82 & 9.53 & 6.55 & 83.92 & 40.56 & 27.11 & [28] \\
\hline CoSBA-15 & 20 & 235 & 1.0 & $16 \mathrm{~L} / \mathrm{g} / \mathrm{h}$ & 2 & $\sim 61$ & 17.3 & 12.5 & 70.2 & $44.0\left(C_{5}-C_{12}\right)$ & $16.8\left(C_{13}-C_{20}\right)$ & [29] \\
\hline Co/ZSM5 & 20 & 240 & 2.0 & $4 \mathrm{~L} / \mathrm{g} / \mathrm{h}$ & 2 & 50.6 & 24.3 & 30.8 & 43.9 & $43.0\left(C_{5}-C_{22}\right)$ & / & [30] \\
\hline $\mathrm{Co} / \mathrm{SBA}-15-\mathrm{CH}$ & 20.1 & 240 & 2.0 & $13.5 \mathrm{~L} / \mathrm{g} / \mathrm{h}$ & 1 & 37.0 & 5.9 & 20.6 & 71.9 & / & / & [31] \\
\hline Co/HZSM-5 & 20 & 251 & 2.0 & $1500 \mathrm{~h}^{-1}$ & 2 & ca. 50 & \multicolumn{2}{|c|}{$30.5\left(C_{1}-C_{4}\right)$} & 69.5 & $48.5\left(C_{5}-C_{12}\right)$ & $14.6\left(C_{13}-C_{18}\right)$ & [32] \\
\hline $\mathrm{Co} / \mathrm{ZS}-0$ & 15 & 240 & 2.0 & $1000 \mathrm{~h}^{-1}$ & 2 & 90.0 & 23.4 & 11.5 & 65.1 & 33.9 & 20.6 & This work \\
\hline $\mathrm{Co} / \mathrm{ZS}-20$ & 15 & 240 & 2.0 & $1000 \mathrm{~h}^{-1}$ & 2 & 90.6 & 13.3 & 7.0 & 79.7 & 32.0 & 29.1 & This work \\
\hline $\mathrm{Co} / \mathrm{ZS}-100$ & 15 & 240 & 2.0 & $1000 \mathrm{~h}^{-1}$ & 2 & 70.5 & 18.5 & 12.0 & 69.5 & 23.9 & 25.8 & This work \\
\hline
\end{tabular}




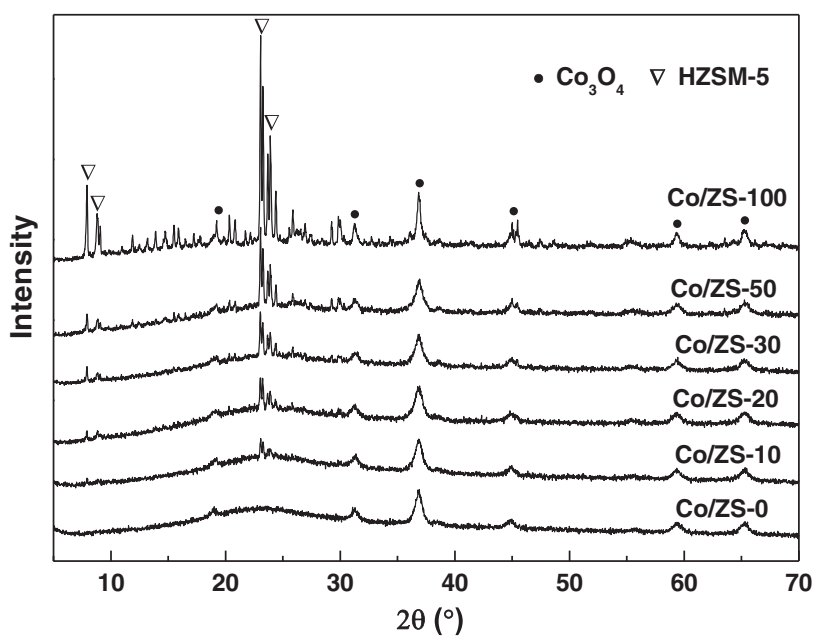

Fig. 1. XRD patterns of the Co/ZS-X series catalysts.

$\mathrm{Co}_{3} \mathrm{O}_{4}$ in the catalysts play a key role in enhancing the FTS activity [38]. The crystal size of $\mathrm{Co}_{3} \mathrm{O}_{4}$ in the $\mathrm{Co} / \mathrm{ZS}-100$ catalyst $(26.0 \mathrm{~nm})$ dramatically exceeded the micropore size of ZSM-5 $(0.53 \times 0.56 \mathrm{~nm}$, IUPAC), indicating that few $\mathrm{Co}_{3} \mathrm{O}_{4}$ particles entered the micropores of $\mathrm{ZSM}-5$ and a large fraction of $\mathrm{CO}_{3} \mathrm{O}_{4}$ located on the external surface of ZSM-5 [35], consistent with the observations in the FTS reactions discussed in the previous section.

\subsection{XPS characterization of catalysts}

The XPS narrow scan spectra for the Co $2 \mathrm{p}$ peaks could illustrate the chemical state and surface distribution of the cobalt species. As shown in Fig. 2, the $\mathrm{Co}_{2} 2 \mathrm{p}_{3 / 2}$ and $\mathrm{Co}_{2} 2 \mathrm{p}_{1 / 2}$ peaks featured at the binding energy (BE) of 780.2-780.8 eV and 795.4-796.1 eV indicate the presence of $\mathrm{Co}^{2+}$ or $\mathrm{Co}^{3+}$ in the $\mathrm{Co}_{3} \mathrm{O}_{4}$ spinel phase [35]. Furthermore, for all samples the doublet separation of the binding energy $(\Delta \mathrm{E})$ between the Co $2 \mathrm{p}_{1 / 2}$ and Co $2 \mathrm{p}_{3 / 2}$ peaks was $14.8-15.4 \mathrm{eV}$, which is close to that of the mixed-valence $\mathrm{Co}_{3} \mathrm{O}_{4}(15.2 \mathrm{eV})$ [39]. Therefore, $\mathrm{Co}_{3} \mathrm{O}_{4}$ was considered the predominant cobalt phase in these catalysts after calcination, in agreement with the XRD results. The shallow features $(789.3 \mathrm{eV})$ on the higher energy side of the main peaks could be ascribed to shake-up satellites associated with some $\mathrm{Co}^{2+}$ in the high spin state [40], particularly evident for the catalyst Co/ZS-100.

The peak intensity of $\mathrm{Co}_{2} 2 \mathrm{p}_{3 / 2}$ became enhanced with increasing $\mathrm{ZSM}-5$ in $\mathrm{Co} / \mathrm{ZS}-\mathrm{x}$ catalysts, indicating the increased content of $\mathrm{Co}_{3} \mathrm{O}_{4}$ on the $\mathrm{Co} / \mathrm{ZS}-\mathrm{x}$ catalyst surface. Note that the escape depth of photoelectrons generated during the XPS analysis is less than $10 \mathrm{~nm}$. Compared with $\mathrm{Co} / \mathrm{ZS}-0$, the surface atomic ratio of $\mathrm{Co} / \mathrm{Si}$ increased with increasing ZSM-5 addition but the Co/Si ratio of Co/ZS-100 was 0.401 , an order of magnitude higher than those of the other catalysts. It is believed that the cobalt particles were enriched on the exterior surface of the ZSM-5 particles but were

Table 4

The crystal size of $\mathrm{Co}_{3} \mathrm{O}_{4}, \mathrm{Co}^{0}$ dispersion and surface atomic ratio of $\mathrm{Co} / \mathrm{Si}$ of the $\mathrm{Co} / \mathrm{ZS}-\mathrm{X}$ series catalysts.

\begin{tabular}{llcl}
\hline Catalyst & $\begin{array}{l}\text { Crystal size of } \\
\mathrm{Co}_{3} \mathrm{O}_{4}(\mathrm{~nm})\end{array}$ & $\begin{array}{l}\mathrm{Co}^{0} \text { dispersion } \\
(\%)\end{array}$ & $\begin{array}{l}\text { Surface atomic } \\
\text { ratio }(\mathrm{Co} / \mathrm{Si})\end{array}$ \\
\hline $\mathrm{Co} / \mathrm{ZS}-0$ & 14.1 & 9.1 & 0.034 \\
$\mathrm{Co} / \mathrm{ZS}-10$ & 12.3 & 10.4 & 0.047 \\
$\mathrm{Co} / \mathrm{ZS}-20$ & 12.1 & 10.6 & 0.075 \\
$\mathrm{Co} / \mathrm{ZS}-30$ & 13.6 & 9.4 & 0.051 \\
$\mathrm{Co} / \mathrm{ZS}-50$ & 14.0 & 9.1 & 0.072 \\
$\mathrm{Co} / \mathrm{ZS}-100$ & 26.0 & 4.9 & 0.401 \\
\hline
\end{tabular}

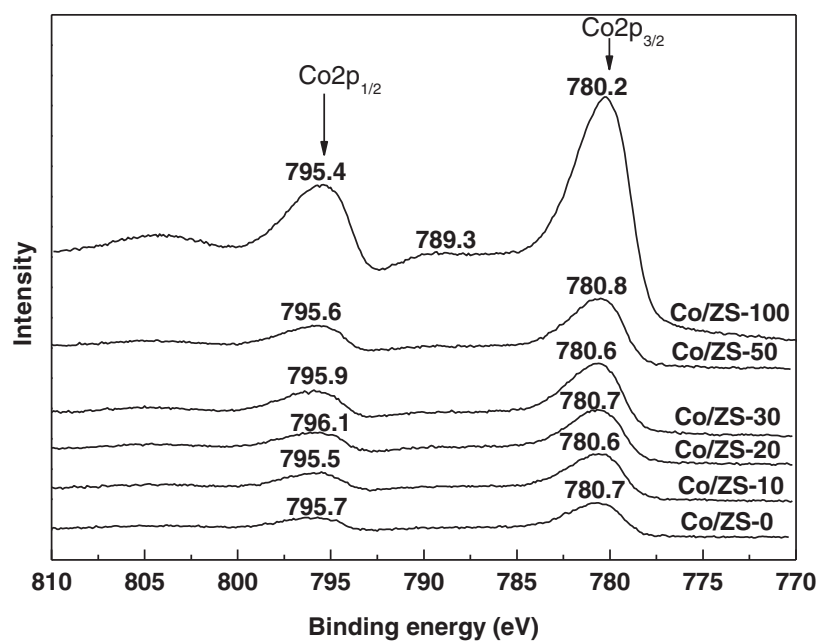

Fig. 2. XPS narrow scan spectra of the Co 2 p region for the Co/ZS-x series catalysts.

distributed on both external and internal surfaces of SBA-15. The disproportional $\mathrm{Co} / \mathrm{Si}$ ratio relative to the amount of ZSM-5 could have resulted from the different ratio of $\mathrm{Co}_{3} \mathrm{O}_{4}$ on the external and internal surfaces of the composite support.

\subsection{Morphology of catalysts}

As can be seen from Fig. 3a and b, Co/ZS-0 (ie. without any ZSM-5 zeolite) consisted of SBA-15 particles of relatively uniform sizes of around $1 \mu \mathrm{m}$. The white dots in Fig. 3b were deemed to be the $\mathrm{CO}_{3} \mathrm{O}_{4}$ particles. The dispersion of the cobalt particles was well distributed. The average crystal size of ZSM-5 in the Co/ZS-100 catalyst was 2-3 $\mu \mathrm{m}$ (Fig. 3d) where the non-uniform small particles observed on the external surface of ZSM-5 were believed to be $\mathrm{Co}_{3} \mathrm{O}_{4}$. The $\mathrm{Co}_{3} \mathrm{O}_{4}$ particles observed on ZSM- 5 were uneven since some cobalt species agglomerated to large particles. From Fig. 3c, both the SBA-15 structures and the ZSM- 5 crystals in the composite can be distinctly observed. The worm-like macrostructures of SBA-15 always aggregated together, and the crystallites of ZSM-5 were distinguished as well.

It can be directly observed from Fig. 4 that SBA-15 had a highly ordered hexagonal arrangement of the channels and the darker contrasts were representative of $\mathrm{Co}_{3} \mathrm{O}_{4}$ located both on the external surface and within the channels (Fig. 4a). A similar distribution was also observed on Co/ZS-20 (Fig. 4b), a cross-sectional view of the SBA-15 channels. The pore size in the SBA-15 structure estimated from Fig. $4 \mathrm{~b}$ was $6.0 \mathrm{~nm}$ and the size of cobalt particles inside the SBA-15 channels in Fig. 4a was $5.9 \mathrm{~nm}$. The darkness observed on ZSM-5 (Fig. 4c) was regarded as $\mathrm{CO}_{3} \mathrm{O}_{4}$ on the external surface of $\mathrm{ZSM}-5$, since the Co signal as well as $\mathrm{Si}$ and $\mathrm{Al}$ signals were observed from the EDS result (Fig. 4d). It can be speculated that most cobalt particles were likely to form on the external surface of ZSM-5, which was in accord with the SEM image and literature reports that the Co species were prone to migrate and aggregate on the surface of ZSM-5 after the incipient wetness impregnation process with higher cobalt content $[35,43]$.

\subsection{Acidic properties of catalysts}

The surface acidity of an FTS catalyst has a strong impact on the in-situ cracking of products formed [7] and was therefore determined for the present catalysts using $\mathrm{NH}_{3}$-TPD with results shown in Fig. 5. All the catalysts, including SBA-15, showed a characteristic peak I at about $104{ }^{\circ} \mathrm{C}$, owning to desorption of the physisorbed $\mathrm{NH}_{3}$ from the $\mathrm{Si}-\mathrm{OH}$ sites on the surface of SBA-15 or ZSM-5 [41]. The broad peak II at around $486{ }^{\circ} \mathrm{C}$ for the single SBA- 15 supported catalyst Co/ZS-0 is 


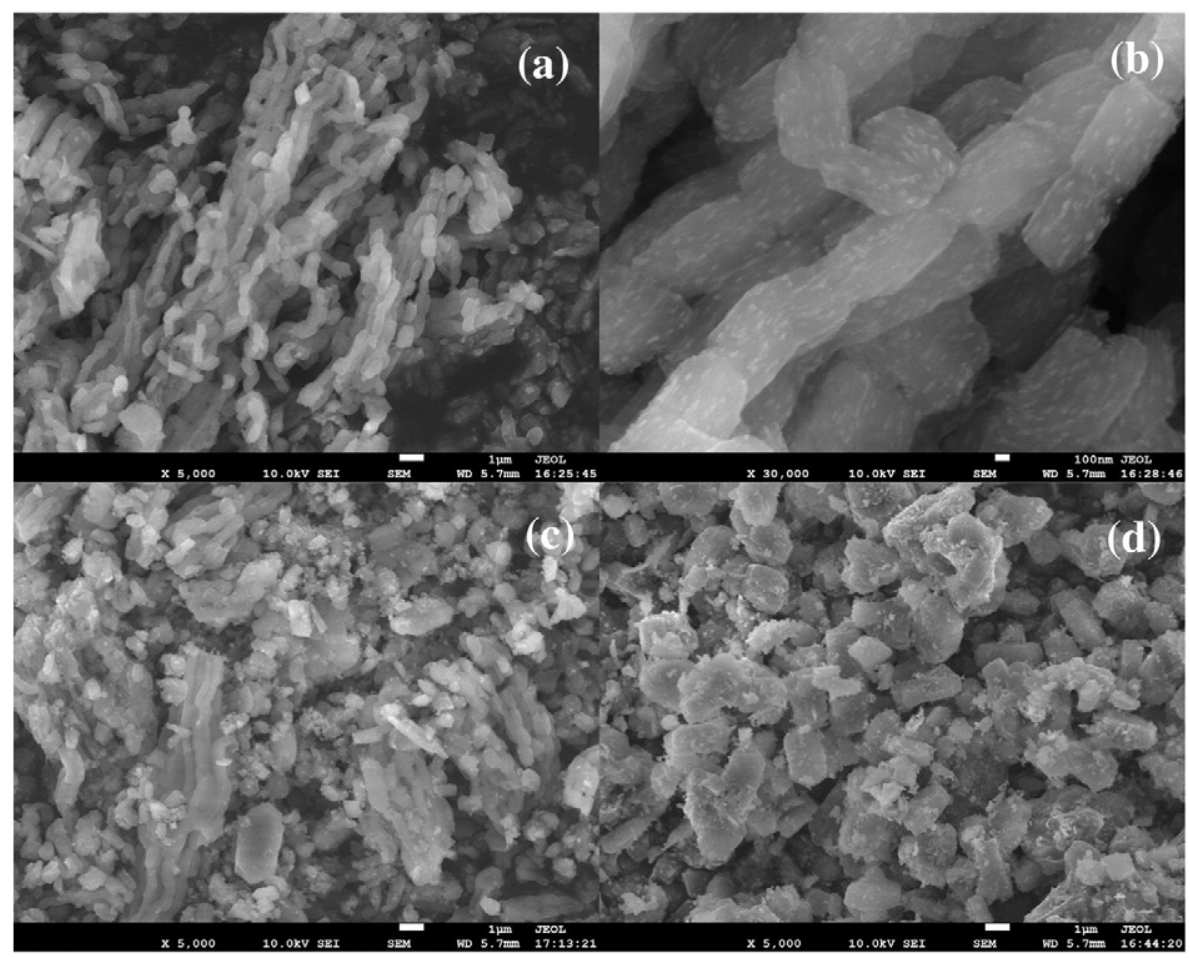

Fig. 3. Typical SEM images of three representative catalyst samples (a) Co/ZS-0; (b) Co/ZS-0 with a larger magnification; and (c) Co/ZS-20; and (d) Co/ZS-100.
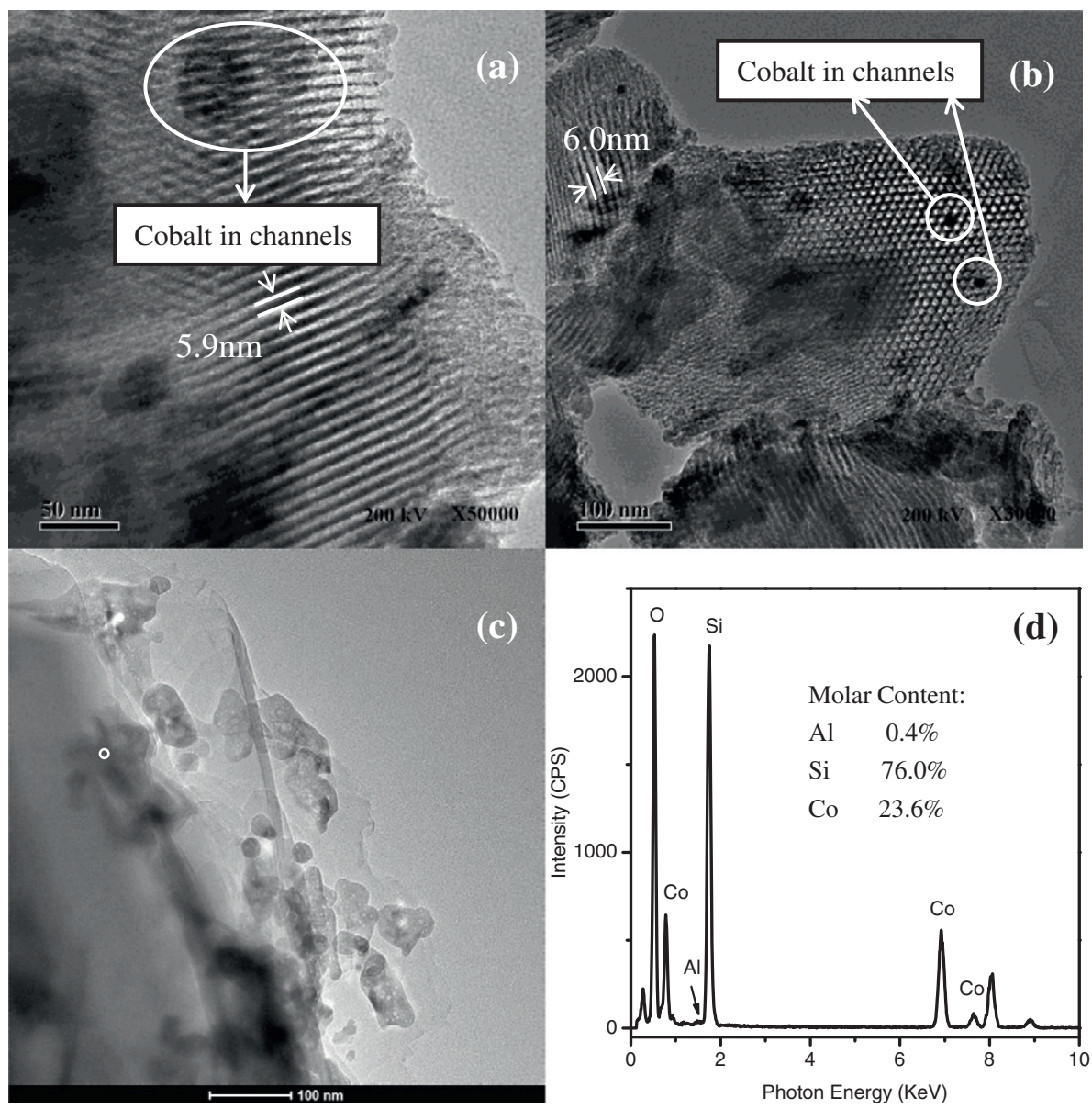

Fig. 4. Typical TEM images of (a) Co/ZS-0; (b) Co/ZS-20; (c) Co/ZS-100; and (d) EDS analysis of point O on Co/ZS-100. 


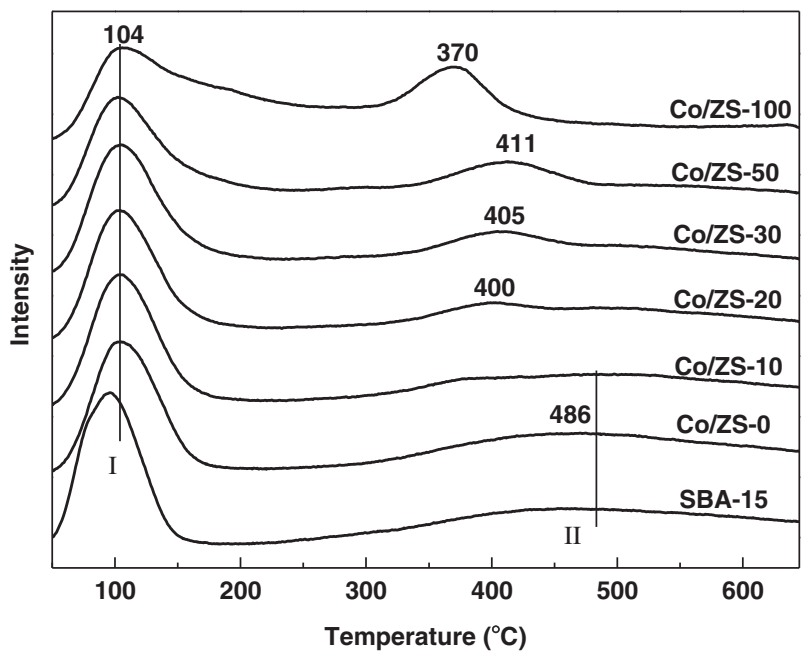

Fig. 5. $\mathrm{NH}_{3}$-TPD curves of the $\mathrm{Co} / \mathrm{ZS}$-X series catalysts.

due to the negligible adsorption of $\mathrm{NH}_{3}$ on the pure SBA-15 [35], while the peak II at $370{ }^{\circ} \mathrm{C}$ for $\mathrm{Co} / \mathrm{ZS}-100$ can be assigned to the aluminium centres of ZSM-5 and the dispersion of $\mathrm{Co}_{3} \mathrm{O}_{4}$ on the support of ZSM-5 [35]. Compared to Co/ZS-0 and Co/ZS-100, peak II for the composite supported catalysts may have originated from the dispersion of $\mathrm{Co}_{3} \mathrm{O}_{4}$ on the support of SBA-15 and ZSM-5 and the aluminium centres of ZSM-5. It was observed that peak II shifted to lower temperatures with increasing ZSM-5 addition up to $20 \mathrm{wt} . \%$, which was in accordance with the literature [35] that the acid strength of the alumina centres of ZSM-5 was less than the dispersion of $\mathrm{Co}_{3} \mathrm{O}_{4}$ on the support. Peak II shifted to higher temperatures for $\mathrm{Co} / \mathrm{ZS}-30$ and $\mathrm{Co} / \mathrm{ZS}-50$ than the $\mathrm{Co} / \mathrm{ZS}-20$ catalyst, indicating the surface coverage of aluminium centres by the larger crystal sizes of $\mathrm{CO}_{3} \mathrm{O}_{4}$. Meanwhile, the intensity of the peak above $350{ }^{\circ} \mathrm{C}$ was enhanced with increasing the amount of ZSM-5, suggesting the increased acid sites arising from the aluminium centres of ZSM-5 [42]. Table 5 gives the acid site density, expressed as $\mathrm{NH}_{3}$ adsorbed in mmol per gram of catalyst on Co/ZS catalysts. Generally, the acid site density increased with an increase in the ZSM-5 content in the composite supports. The acid sites could cause the cracking and isomerization of heavier hydrocarbons generated on the surface cobalt sites. However, the acid sites with high strength could also result in the over-cracking to undesired light hydrocarbons $\left(\mathrm{CH}_{4}\right.$ and $\mathrm{C}_{2}-\mathrm{C}_{4}$ alkanes). Co/ZS-20 was found to be the best for the production of middle hydrocarbons, which seems to be consistent with the amount of acid sites on this catalyst.

\subsection{Reduction behaviour of catalysts}

The activity of FTS catalysts strongly depends on the reducibility of the $\mathrm{Co}_{3} \mathrm{O}_{4}$ species and the $\mathrm{H}_{2}$-TPR was performed on the present catalysts to assess their reduction behaviour of $\mathrm{CO}_{3} \mathrm{O}_{4}$. The TPR profiles

Table 5

Physicochemical properties of the catalysts.

\begin{tabular}{lllll}
\hline Catalyst & $\begin{array}{l}\mathrm{H}_{2} \text { consumption } \\
\text { below } 450^{\circ} \mathrm{C} \\
(\mathrm{mmol} / \mathrm{g})\end{array}$ & $\begin{array}{l}\text { Overall } \mathrm{H}_{2} \\
\text { consumption } \\
(\mathrm{mmol} / \mathrm{g})\end{array}$ & $\begin{array}{l}\text { Degree of } \\
\text { reduction } \\
(\%)^{\mathrm{a}}\end{array}$ & $\begin{array}{l}\mathrm{NH}_{3} \\
\text { uptake } \\
(\mathrm{mmol} / \mathrm{g})\end{array}$ \\
\hline $\mathrm{Co} / \mathrm{ZS}-0$ & 1.47 & 2.84 & 51.8 & 2.58 \\
$\mathrm{Co} / \mathrm{ZS}-10$ & 1.50 & 2.84 & 52.8 & 2.41 \\
$\mathrm{Co} / \mathrm{ZS}-20$ & 1.34 & 2.77 & 48.3 & 2.63 \\
$\mathrm{Co} / \mathrm{ZS}-30$ & 1.34 & 2.77 & 48.4 & 2.69 \\
$\mathrm{Co} /$ ZS-50 & 1.36 & 2.58 & 52.7 & 2.50 \\
$\mathrm{Co} / \mathrm{ZS}-100$ & 1.83 & 2.39 & 76.5 & 2.90 \\
\hline
\end{tabular}

a The degree of reduction is calculated by dividing the $\mathrm{H}_{2}$ consumption below $450^{\circ} \mathrm{C}$ by the total amount of $\mathrm{H}_{2}$ consumption by the catalysts. shown in Fig. 6 allowed the degree of reduction to be estimated by dividing the $\mathrm{H}_{2}$ consumption below $450^{\circ} \mathrm{C}$ by the total $\mathrm{H}_{2}$ consumption by the catalysts as summarized in Table 5 . Fig. 6 shows two distinct reduction peaks, peak I at around $320^{\circ} \mathrm{C}$ and peak II at about $450{ }^{\circ} \mathrm{C}$, on the $\mathrm{H}_{2}$-TPR profiles for the catalysts containing less than $50 \%$ ZSM-5. The reduction of $\mathrm{Co}_{3} \mathrm{O}_{4}$ was a two-step process involving the reduction of $\mathrm{Co}^{3+}$ to $\mathrm{Co}^{2+}$ at a low temperature and the subsequent reduction of $\mathrm{CoO}$ to metallic $\mathrm{Co}$ at a high temperature [43]. Therefore, peak I may be attributed to the reduction of $\mathrm{Co}^{3+}$ to $\mathrm{Co}^{2+}$ and peak II to the reduction of $\mathrm{CoO}$ to metallic $\mathrm{Co}$ in the present work. The temperature of peak I incurred little alternation (at around $324^{\circ} \mathrm{C}$ ) while the addition of ZSM-5 in the composite support was increased up to 30wt.\%, but was shifted to lower temperatures (at $316{ }^{\circ} \mathrm{C}$ and $312{ }^{\circ} \mathrm{C}$ ) with further addition of ZSM-5 at 50wt.\% and 100wt.\%. However, the temperature of peak II of the broad profiles comprised of more than one peak was decreased from $460{ }^{\circ} \mathrm{C}$ to $445^{\circ} \mathrm{C}$, which is thought to be caused by the coaction of different-sized particles and varying degrees of interaction between the cobalt species and the support [36]. The easy reduction had resulted from the large crystal sizes and the weak interaction between the cobalt species and support. The effect of crystal size of $\mathrm{Co}_{3} \mathrm{O}_{4}$ was typical for the reduction of $\mathrm{CoO}$ to metallic $\mathrm{Co}$ (peak II), therefore, the Co/ZS-100 catalyst with the much larger crystal sizes displayed an much easier reduction behaviour at $362{ }^{\circ} \mathrm{C}$, which was in good agreement with the literature reports $[12,44]$. The degree of reduction for Co/ZS-100 was $76.5 \%$, the highest among the catalysts. The greater extent of reduction facilitated the production of long-chain hydrocarbon products [14]. In addition to the two main reduction peaks, a third peak at around $650{ }^{\circ} \mathrm{C}$ (peak III) was also observed for Co/ZS-50 and Co/ZS-100, being more apparent on the latter. This might be caused by the reduction of more stable species, such as cobalt aluminate or cobalt silicate on the ZSM-5 support [45]. The high $\mathrm{CH}_{4}$ selectivity of FTS over $\mathrm{Co} / \mathrm{ZS}-0$ and the large amount of $\mathrm{C}_{23}$ + production over Co/ZS-100 were consistent with the literature report [24] that the $\mathrm{CH}_{4}$ selectivity was enhanced on the $\mathrm{CoO}$ surface and the high reducibility of $\mathrm{Co}_{3} \mathrm{O}_{4}$ was beneficial to the production of long-chain hydrocarbons.

\section{Conclusions}

The ZSM-5/SBA-15 composite supported catalysts were shown to have the superior catalytic performance as compared to the single material supported catalysts. The selectivity profiles of the $C_{1}-C_{4}$ and $\mathrm{C}_{5}-\mathrm{C}_{22}$ ranges of hydrocarbons took a volcanic shape for the catalysts with increasing amount of ZSM-5 in the support. The catalyst with 20wt.\% ZSM-5 in the support shifted the product distribution to the

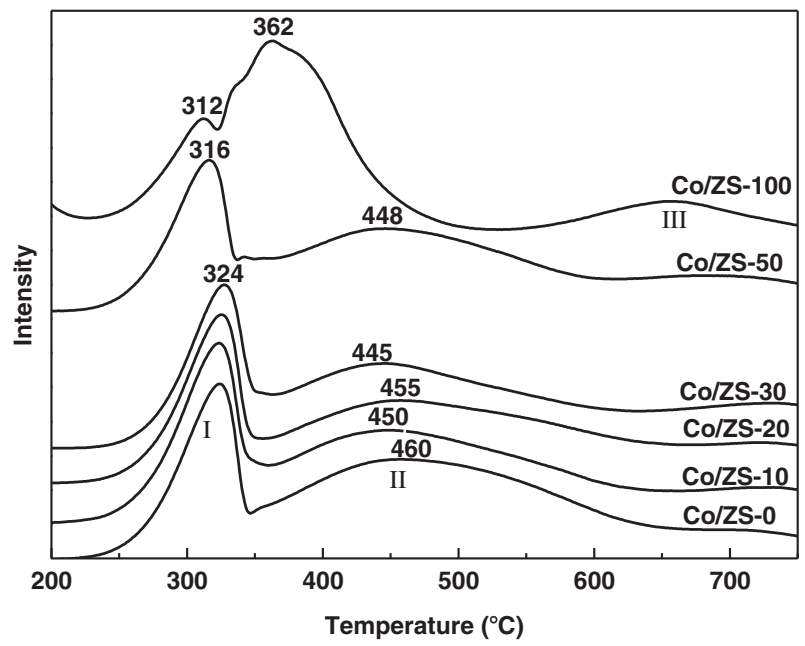

Fig. 6. $\mathrm{H}_{2}$-TPR profiles of the $\mathrm{Co} / \mathrm{ZS}-\mathrm{x}$ series catalysts. 
middle distillate range of hydrocarbons, with minimum selectivity of $\mathrm{C}_{1}-\mathrm{C}_{4}$ and maximum selectivity of $\mathrm{C}_{5}-\mathrm{C}_{22}$. More light hydrocarbons $\left(\mathrm{CH}_{4}\right.$ and $\mathrm{C}_{2}-\mathrm{C}_{4}$ alkanes) were produced with further addition of ZSM-5. The composite support with 20wt.\% ZSM-5 showed the optimal amount and strength of acid sites for the cracking of heavier hydrocarbons to $\mathrm{C}_{5}-\mathrm{C}_{22}$.

\section{Acknowledgements}

This work was financially supported by the Ministry of Science and Technology of the People's Republic of China (Project No. 2010BAC66B03), Chinese Academy of Sciences (Project No. XDA07070301 and Project No. Y2010022), Entrepreneurial and Innovative Leading Talent Project of Qingdao (13-CX-19) and the Australian Research Council under the ARC Linkage Projects scheme (ARC LP100200136).

\section{References}

[1] J. Kang, S. Zhang, Q. Zhang, Y. Wang, Ruthenium nanoparticles supported on carbon nanotubes as efficient catalysts for selective conversion of synthesis gas to diese fuel, Angew. Chem. Int. Ed. 48 (2009) 2565-2568.

[2] Q. Zhang, J. Kang, Y. Wang, Development of novel catalysts for Fischer-Tropsch synthesis: tuning the product selectivity, ChemCatChem 2 (2010) 1030-1058.

[3] M.E. Dry, High quality diesel via the Fischer-Tropsch process-a review, J. Chem. Technol. Biotechnol. 77 (2002) 43-50.

[4] M. Stelmachowski, L. Nowicki, Fuel from the synthesis gas-the role of process engineering, Appl. Energy 74 (2003) 85-93.

[5] D.N. Vo, V. Arcotumapathy, B. Abdullah, A.A. Adesina, Evaluation of Ba-promoted Mo carbide catalyst for Fischer-Tropsch synthesis, J. Chem. Technol. Biotechnol. 88 (2013) 1358-1363.

[6] X. Liu, A. Hamasaki, T. Honma, M. Tokunaga, Anti-ASF distribution in FischerTropsch synthesis over unsupported cobalt catalysts in a batch slurry phase reactor, Catal. Today 175 (2011) 494-503.

[7] J. Kang, K. Cheng, L. Zhang, O. Zhang, J. Ding, W. Hua, Y. Lou, O. Zhai, Y. Wang, Mesoporous zeolite-supported Ruthenium nanoparticles as highly selective Fischer-Tropsch catalysts for the production of $C_{5}-C_{11}$ isoparaffins, Angew. Chem. Int. Ed. 50 (2011) 5200-5203.

[8] L. Yu, X. Liu, Y. Fang, C. Wang, Y. Sun, Highly active Co/SiC catalysts with controllable dispersion and reducibility for Fischer-Tropsch synthesis, Fuel 112 (2013) 483-488.

[9] M. Dalil, M. Sohrabi, S.J. Royaee, Application of nano-sized cobalt on ZSM-5 zeolite as an active catalyst in Fischer-Tropsch synthesis, J. Ind. Eng. Chem. 18 (2012) 690-696.

[10] N.S. Hondow, G.A. Koutsantonis, R.O. Fuller, H. Fansuri, M. Saunders, R.L. Stamps, D Zhang, The modification of M41S materials: addition of metal clusters and nanoparticles, New J. Chem. 34 (2010) 1286-1294.

[11] M. Khobragade, S. Majhi, K.K. Pant, Effect of $\mathrm{K}$ and $\mathrm{CeO}_{2}$ promoters on the activity of $\mathrm{Co} / \mathrm{SiO}_{2}$ catalyst for liquid fuel production from syngas, Appl. Energy 94 (2012 385-394.

[12] A. Martinez, C. López, F. Márquez, I. Diaz, Fischer-Tropsch synthesis of hydrocarbons over mesoporous Co/SBA-15 catalysts: the influence of metal loading, cobalt precursor, and promoters, J. Catal. 220 (2003) 486-499.

[13] A.Y Khodakov, R. Bechara, A Griboval-Constant, Fischer-Tropsch synthesis ove silica supported cobalt catalysts: mesoporous structure versus cobalt surface density, Appl. Catal. A Gen. 254 (2003) 273-288.

14] A.Y. Khodakov, A. Griboval-Constant, R. Bechara, V.L. Zholobenko, Pore size effects in Fischer Tropsch synthesis over cobalt-supported mesoporous silicas, J. Catal. 206 (2002) 230-241

[15] H. Xiong, Y. Zhang, K. Liew, J. Li, Fischer-Tropsch synthesis: the role of pore size for Co/SBA-15 catalysts, J. Mol. Catal. A Chem. 295 (2008) 68-76.

[16] F.G. Botes, W. Böhringer, The addition of HZSM-5 to the Fischer-Tropsch process for improved gasoline production, Appl. Catal. A Gen. 267 (2004) 217-225

117] A. Martínez, J. Rollán, M.A. Arribas, H.S. Cerqueira, A.F. Costa, E.F. S.-Aguiar, A detailed study of the activity and deactivation of zeolites in hybrid $\mathrm{Co} / \mathrm{SiO}_{2}$-zeolite Fischer-Tropsch catalysts, J. Catal. 249 (2007) 162-173.

[18] Y. Li, T. Wang, C. Wu, H. Li, X. Qin, N. Tsubaki, Gasoline-range hydrocarbon synthesis over $\mathrm{Co} / \mathrm{SiO}_{2} / \mathrm{HZSM}-5$ catalyst with $\mathrm{CO}_{2}$-containing syngas, Fuel Process. Technol. 91 (2010) 388-393.

[19] S. Sartipi, K. Parashar, M.J. Valero-Romero, V.P. Santos, B. van der Linden, M. Makkee F. Kapteijn, J. Gascon, Hierarchical H-ZSM-5-supported cobalt for the direct synthesis of gasoline-range hydrocarbons from syngas: advantages, limitations, and mechanistic insight, J. Catal. 305 (2013) 179-190.
[20] Z. Di, C. Yang, X. Jiao, J. Li, J. Wu, D. Zhang, A ZSM-5/MCM-48 based catalyst for methanol to gasoline conversion, Fuel 104 (2013) 878-881.

[21] Y. Shen, Q. Zhao, X. Li, D. Zhang, Monodisperse $\mathrm{Ca}_{0.15} \mathrm{Fe}_{2.85} \mathrm{O}_{4}$ microspheres: facile preparation, characterization, and optical properties, J. Mater. Sci. 47 (2012) 3320-3326.

[22] J. Liu, X. Li, Q. Zhao, D. Zhang, CuO supportd Ce-Ti mixed oxides for lowtemperature SCR of NO with propene, Adv. Mater. Res. 518-523 (2012) 2456-2459.

[23] E.P. Barrett, L.G. Joyner, P.P. Halenda, The determination of pore volume and area distributions in porous substances. I. Computations from nitrogen isotherms, J. Am. Chem. Soc. 73 (1951) 373-380.

[24] A.R. de la Osa, A. de Lucas, L. Sánchez-Silva, J. Díaz-Maroto, J.L. Valverde, P. Sánchez, Performing the best composition of supported $\mathrm{Co} / \mathrm{SiC}$ catalyst for selective FTS diesel production, Fuel 95 (2012) 587-598.

[25] S. Storsæter, B. Tøtdal, J.C. Walmsley, B.S. Tanem, A. Holmen, Characterization of alumina-, silica-, and titania-supported cobalt Fischer-Tropsch catalysts, J. Catal. 236 (2005) 139-152.

[26] O. González, H. Pérez, P. Navarro, L.C. Almeida, J.G. Pacheco, M. Montes, Use of different mesostructured materials based on silica as cobalt supports for the Fischer-Tropsch synthesis, Catal. Today 148 (2009) 140-147.

[27] G. Prieto, A. Martínez, R. Murciano, M.A. Arribas, Cobalt supported on morphologically tailored SBA-15 mesostructures: the impact of pore length on metal dispersion and catalytic activity in the Fischer-Tropsch synthesis, Appl. Catal. A Gen. 367 (2009) 146-156.

[28] L. Jia, L. Jia, D. Li, B. Hou, J. Wang, Y. Sun, Silylated Co/SBA-15 catalysts for FischerTropsch synthesis, J. Solid State Chem. 184 (2011) 488-493.

[29] Q.Q. Hao, Y.H. Zhao, H.H. Yang, Z.T. Liu, Z.W. Liu, Alumina grafted to SBA-15 in supercritical $\mathrm{CO}_{2}$ as a support of cobalt for Fischer-Tropsch synthesis, Energy Fuel 26 (2012) 6567-6575.

[30] S.H. Kang, J.H. Ryu, J.H. Kim, I.H. Jang A.R. Kim, G.Y. Han, J.W. Bae, K.S. Ha, Role of ZSM5 distribution on $\mathrm{Co} / \mathrm{SiO}_{2}$ Fischer-Tropsch catalyst for the production of $C_{5}-C_{22}$ hydrocarbons, Energy Fuel 26 (2012) 6061-6069.

[31] J.J. Rodrigues, F.A.N. Fernandes, M.G.F. Rodrigues, Study of Co/SBA-15 catalysts prepared by microwave and conventional heating methods and application in Fischer-Tropsch synthesis, Appl. Catal. A Gen. 468 (2013) 32-37.

[32] S. Wang, Q. Yin, J. Guo, B. Ru, L. Zhu, Improved Fischer-Tropsch synthesis for gasoline over Ru, Ni promoted Co/HZSM-5 catalysts, Fuel 108 (2013) 597-603.

[33] S. Bessell, ZSM-5 as a support for cobalt Fischer-Tropsch catalysts, in: H.E. Curry-Hyde, R.F. Howe (Eds.), Studies in Surface Science and Catalysis, vol. 81, Elsevier, 1994, pp. 461-466.

[34] L.B. Pierella, C. Saux, S.C. Caglieri, H.R. Bertorello, P.G. Bercoff, Catalytic activity and magnetic properties of Co-ZSM-5 zeolites prepared by different methods, Appl. Catal. A Gen. 347 (2008) 55-61.

[35] F. Bin, C. Song, G. Lv, J. Song X. Cao, H. Pang K. Wang Structural characterization and selective catalytic reduction of nitrogen oxides with ammonia: a comparison between Co/ZSM-5 and Co/SBA-15, J. Phys. Chem. C 116 (2012) 26262-26274.

[36] Ø. Borg, S. Eri, E.A. Blekkan, S. Storsæter, H. Wigum, E. Rytter, A. Holmen, FischerTropsch synthesis over $\gamma$-alumina-supported cobalt catalysts: effect of support variables, J. Catal. 248 (2007) 89-100.

[37] A. Monshi, Modified Scherrer equation to estimate more accurately nano-crystallite size using XRD, World J. Nano Sci. Eng. 2 (2012) 154-160.

[38] N. Fischer, E. van Steen, M. Claeys, Structure sensitivity of the Fischer-Tropsch activity and selectivity on alumina supported cobalt catalysts, J. Catal. 299 (2013) 67-80.

[39] J.Y. Luo, M. Meng, X. Li, X.G. Li, Y.O. Zha, T.D. Hu, Y.N. Xie, J. Zhang, Mesoporous $\mathrm{Co}_{3} \mathrm{O}_{4}-\mathrm{CeO}_{2}$ and $\mathrm{Pd} / \mathrm{Co}_{3} \mathrm{O}_{4}-\mathrm{CeO}_{2}$ catalysts: synthesis, characterization and mechanistic study of their catalytic properties for low-temperature $\mathrm{CO}$ oxidation, J. Catal. 254 (2008) 310-324.

[40] H. Xiong, Y. Zhang, K. Liew, J. Li, Ruthenium promotion of Co/SBA-15 catalysts with high cobalt loading for Fischer-Tropsch synthesis, Fuel Process. Technol. 90 (2009) 237-246.

[41] A. Corma, From microporous to mesoporous molecular sieve materials and their use in catalysis, Chem. Rev. 97 (1997) 2373-2420.

[42] U.V. Mentzel, K.T. Højholt, M.S. Holm, R. Fehrmann, P. Beato, Conversion of methanol to hydrocarbons over conventional and mesoporous H-ZSM-5 and H-Ga-MFI: major differences in deactivation behavior, Appl. Catal. A Gen. 417-418 (2012) 290-297.

[43] Z.Zhu, G. Lu, Z. Zhang, Y. Guo, Y. Guo, Y. Wang, Highly active and stable $\mathrm{Co}_{3} \mathrm{O}_{4} / \mathrm{ZSM}-5$ catalyst for propane oxidation: effect of the preparation method, ACS Catal. 3 (2013) 1154-1164.

[44] A.Y. Khodakov, A. Griboval-Constant, R. Bechara, F. Villain, Pore-size control of cobalt dispersion and reducibility in mesoporous silicas, J. Phys. Chem. B 105 (2001) 9805-9811.

[45] S.H. Kang, J.H. Ryu, J.H. Kim, P.S. Sai Prasad, J. Bae, J.Y. Cheon, K.W. Jun, ZSM-5 supported cobalt catalyst for the direct production of gasoline range hydrocarbons by Fischer-Tropsch synthesis, Catal. Lett. 141 (2011) 1464-1471. 